\title{
当科に括ける軟部好酸球肉芽腫症（木村病）の検討
}

\author{
鎌田＼cjkstart利彦・高橋 廣臣・古川 浩三・古沢 慎一
}

\section{Eosinophilic Granuloma in the Soft Tissue (Kimura's Disease)}

Toshihiko Kamata, Hiroomi Takahashi, Kozo Furukawa and Shinichi Furusawa

(Kitasato University School of Medicine) \begin{abstract}
disease.
We report 11 patients with eosinophilic granuloma in the soft tissue or Kimura's

The patients were 8 males and 3 females. The eosinophilic granuloma may occur not merely subcutaneously but also submucosaly in Kimura's disease because the granuloma was detected at the epipharyngeal opening of the auditory tube in one case of the disease with parotid tumor. There was a tendency in the recurrence of the disease to be delayed when the number of eosinophilic leukocytes in the peripheral circulation had been reduced to the normal range after treatment. In radiation therapy, $20 \mathrm{~Gy}$ was enough to abolish or to reduce the size of granuloma and combination radiotherapy with steroids was more effective than simple irradiation to prevent recurrence.
\end{abstract}

Key words: Kimura's disease, eosinophilic leukocytes, radiotherapy

はじめに

軟部好酸球肉芽腫症（木村病）は主として顔

面，頸部などの皮下軟部組織，リンパ節に無痛 性の腫瘤を形成し，慢性の経過をたどる良性疾 患であり, 特徵的な病理組織像と, 末梢血液中 の高好酸球血症, 高 IgE IfII症等により診断さ れる. しかしその原因はいまだ不明であり, 確 立された治療法がなく，再燃しやすい。我々は 開院以来19年間に経験した同症につき臨床的立 場より検討したので報告する。

\section{症例}

当科が経験した同症例は11例（表 1）であり， 男性 8 例女性 3 例であった。

臨床所見: 推定発症年齢は最低年齢 4 歳, 最 高年齢60歳で平均年齢は 38.7 歳 (30歳以下 5 例)
であった。また平均罹病期間は11年であり症例 4 では30年間放置されていた。発症部位は耳下 腺部 7 例, 耳後部 3 例, 顎下部 3 例であり, 単 発例は 8 例, 多発例は 3 例であった。 大きさは 拇指頭大から手拳大で, 罹病期間との関係は認 められない，病変部に一致して局所掇痒感のあ る例は 9 例, カルテに色素沈着の記載を認める ものは 2 例, 頸部リンパ節を触知できたのは 2 例であった。 また耳下腺腫脹例で，患側に一致 して耳管開口部腫瘤を認めた. 即時型カンジダ 皮内反応は施行 3 例とも陰性であった. 合併症 としては尿崩症, DLE (discoid lupus erythematosus), ネフローゼ症候群を各 1 例認めた.

画像診断：CT スキャンでは腫瘤は被膜を有 せず，境界不明膫な均一性病変と内部に一部䨢 


\begin{tabular}{|c|c|c|c|c|c|c|c|c|c|c|c|c|c|c|c|}
\hline$=$ & 蓝 & $\stackrel{10}{N}$ & $\stackrel{\infty}{\infty}$ & 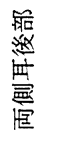 & 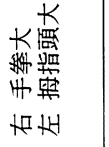 & 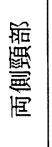 & + & 1 & 1 & & 慗 & 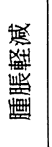 & $\begin{array}{l}\stackrel{8}{2} \\
\stackrel{a}{\cong}\end{array}$ & $\stackrel{\mathscr{N}}{\circ}$ & $\begin{array}{l}\text { 号高 } \\
\text { N v v }\end{array}$ \\
\hline 으 & 聯 & \& & $\overrightarrow{i n}$ & 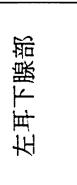 & 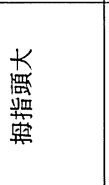 & 1 & + & 1 & 1 & & 淣 & 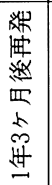 & $\begin{array}{l}\stackrel{8}{2} \\
\text { is }\end{array}$ & $\sigma$ & 孚 \\
\hline$\sigma$ & 蓄 & $\stackrel{\infty}{\infty}$ & ळ్ల & 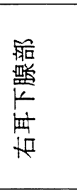 & 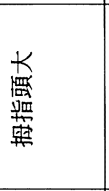 & 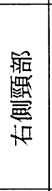 & + & 1 & 1 & 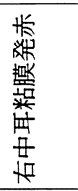 & 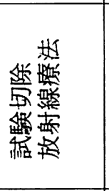 & 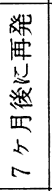 & $\begin{array}{l}8 \\
0 \\
\infty\end{array}$ & $\&$ & 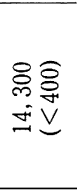 \\
\hline$\infty$ & $\frac{H}{d x}$ & ஜे & $\hat{m}$ & 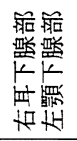 & 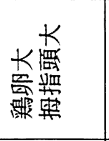 & 1 & + & 1 & 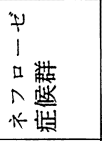 & & 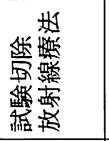 & 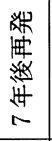 & $\begin{array}{l}8 \\
\text { d } \\
0\end{array}$ & న & 1 \\
\hline$\sim$ & $\frac{d}{d x}$ & I8 & in & 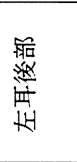 & 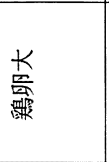 & 1 & + & + & 1 & & 卧 & 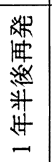 & $\begin{array}{l}8 \\
\text { is } \\
\infty\end{array}$ & $\stackrel{\infty}{\infty}$ & 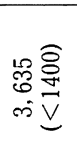 \\
\hline 0 & 蓄 & in & $\hat{\sigma}$ & 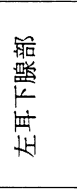 & 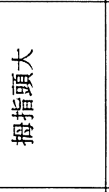 & 1 & 1 & 1 & 1 & 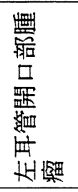 & 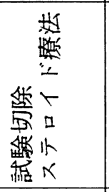 & 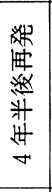 & $\begin{array}{l}8 \\
\vdots \\
\text { in }\end{array}$ & $F$ & 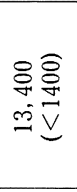 \\
\hline סו & $\frac{H}{k}$ & 8 & $\ddot{8}$ & 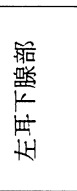 & 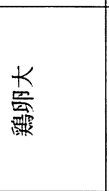 & 1 & + & 1 & 1 & 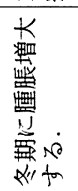 & 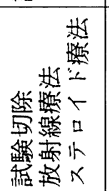 & 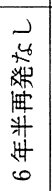 & $\begin{array}{l}8 \\
\text { \& } \\
\text { is }\end{array}$ & $\stackrel{\mathscr{N}}{\mathfrak{L}}$ & 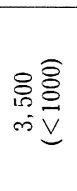 \\
\hline$\nabla$ & 苕 & P & in & 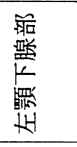 & 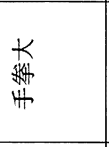 & 1 & + & + & 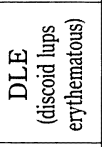 & & 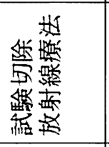 & 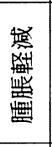 & 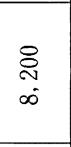 & 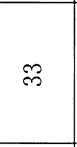 & 1 \\
\hline$\infty$ & 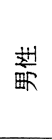 & $\sigma$ & $\vec{m}$ & 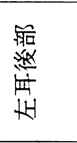 & 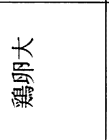 & 1 & + & 1 & 1 & & 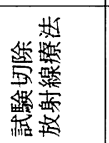 & 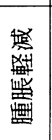 & $\begin{array}{l}8 \\
8 \\
0\end{array}$ & $F$ & 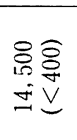 \\
\hline$\sim$ & 蒉 & $\stackrel{\infty}{\sigma}$ & $\stackrel{8}{\circ}$ & 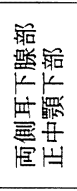 & 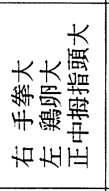 & 1 & 1 & 1 & 1 & 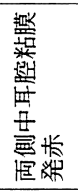 & 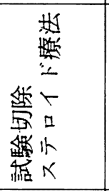 & 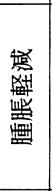 & $\begin{array}{l}\stackrel{8}{0} \\
\stackrel{0}{0}\end{array}$ & is & 1 \\
\hline- & 蓄 & $=$ & $\Xi$ & 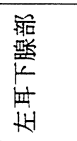 & 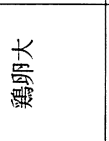 & 1 & 1 & 1 & 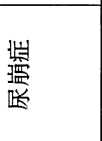 & & 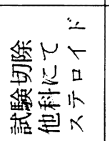 & 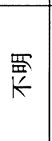 & $\underset{\infty}{\stackrel{8}{\infty}}$ & $\exists$ & 1 \\
\hline 포 & $\begin{array}{l}\# \\
\#\end{array}$ & 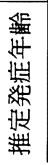 & 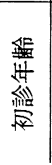 & 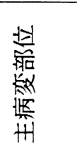 & 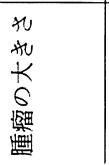 & 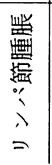 & 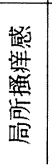 & 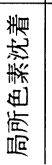 & $\begin{array}{l}\text { 䕀 } \\
\text { 进 } \\
\text { 如 }\end{array}$ & 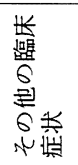 & $\begin{array}{l}\text { 好 } \\
\text { 的 }\end{array}$ & 监 & 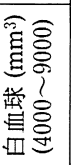 & 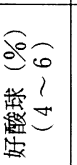 & 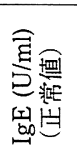 \\
\hline
\end{tabular}


胞様変化を来す例が 4 例中 2 例に認められ，同 様の所見が超音波検査法からもらかがえた. (図

1) Gaシンチでは施行 5 例全例に病変部に一 致して集積像を認めた。

初診時末梢血所見（表 1 , 図 2 ）：白血球数 は正常值上限加軽度増加を示し，好酸球百分 率は症例10を除いて著名に増加していた。同症

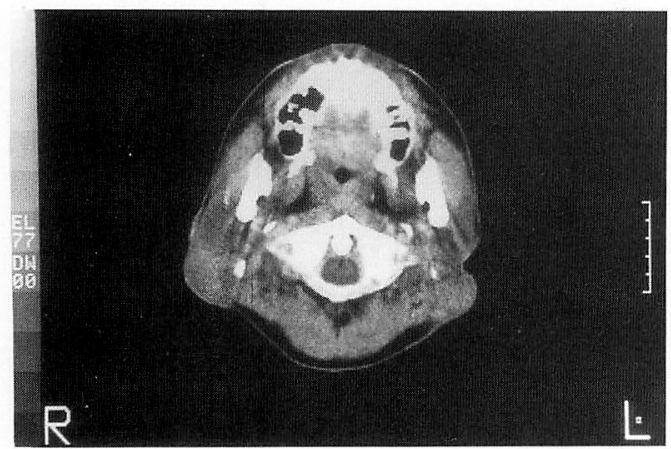

図 1 両側耳後部に造影されない境界不明膫な腫 瘤を認め右側は一部陰影像を呈する。（症 例11)
例は病理組織学的に診断されていた。また，免 疫グロブリンのうち血清 $\operatorname{IgE}$ 抗体測定例は全 例高值を示した。

病理組織学的所見：全例に試験切除を施行し， 注湆同様の所見を呈した，H-E 染色では，膠 原線維と思われる結合組織に囲まれて，大小の 沪胞様構造をとり，層状に配列する成熟リンパ 球と肧中心部に樹脂状細胞, リン, 芽球様細胞, 成熟リンパ球を認めた。沪胞様構造間には好酸 球，形質細胞，リンパ球，肥満細胞の浸潤を呈 していた。（図 3 )

治療方法：2 例に摘出術を行い，症例 7 では 摘出創に大腿部より植皮を行っている。ステロ イド単独療法は 3 例, 放射線単独療法は 5 例, ステロイド，放射線併用療法は 1 例であった。

治療経過：手術療法では術後経過は順調であ ったがいずれも 1 年半以内に再燃した。 ステロ イド単独療法では, 症例 2 で Predonisolone $20 \mathrm{mg}$ より開始し，腫瘤部の軽減をみたが漸減すると 増大しコントロール不能であった。 また症例 6
白血球 数

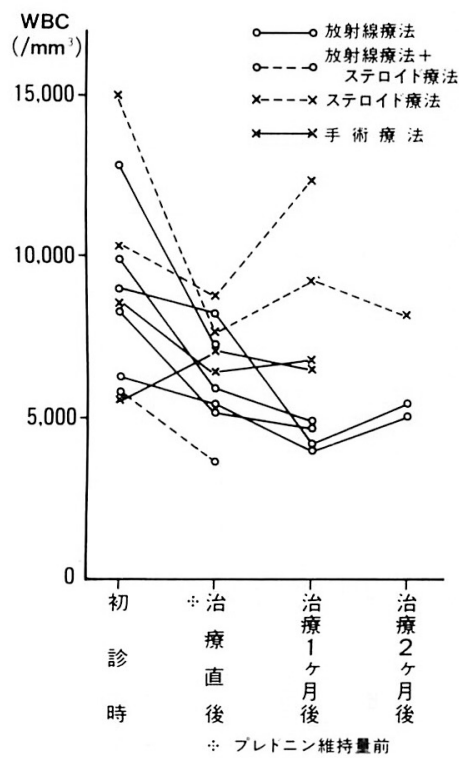

好酸球百分率

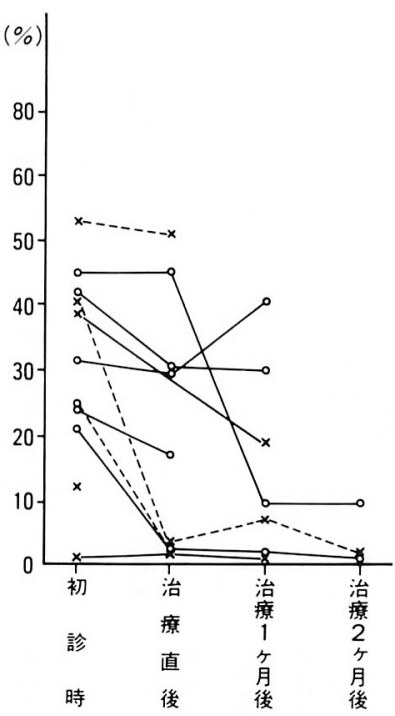

血 清 $\mathrm{IgE}$ 值

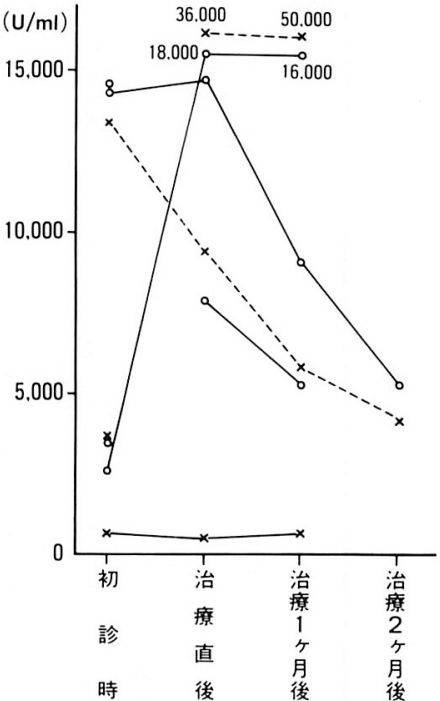

図 2 末梢血液中の白血球数, 好酸球百分率, 血清 $\operatorname{IgE}$ 值 
では Predonisolone $60 \mathrm{mg}$ より漸減し $5 \mathrm{mg}$ を 維持量として良好であったが 4 年半後に再燃し ている。放射線単独療法は, 頸部リンパ節触知 例では large field とし，一門または二門照射， 総量 $20 \mathrm{~Gy}$ とした。腫瘤は $10 \mathrm{~Gy}$ 前後より縮小 しはじめ放射線終了後 2 週間前後で消失または 著明縮小した。ステロイド，放射線併用療法の 症例は Predonisolone $30 \mathrm{mg}$ より漸減し $5 \mathrm{mg}$ を維持量として他院にて 35 Gy の照射を受けた 例で， 6 年半の経過観察では再燃を見ていない. しかし長期的に経過を追えた症例では，ほとん ぞが再燃して持り同症の治療の困難さと定期的 な経過観察の必要性をらかがわせた。

治療後の末梢血液学的検索 : (図 2 ) 白血球 数は治療直後では正常範囲に納まっているが，
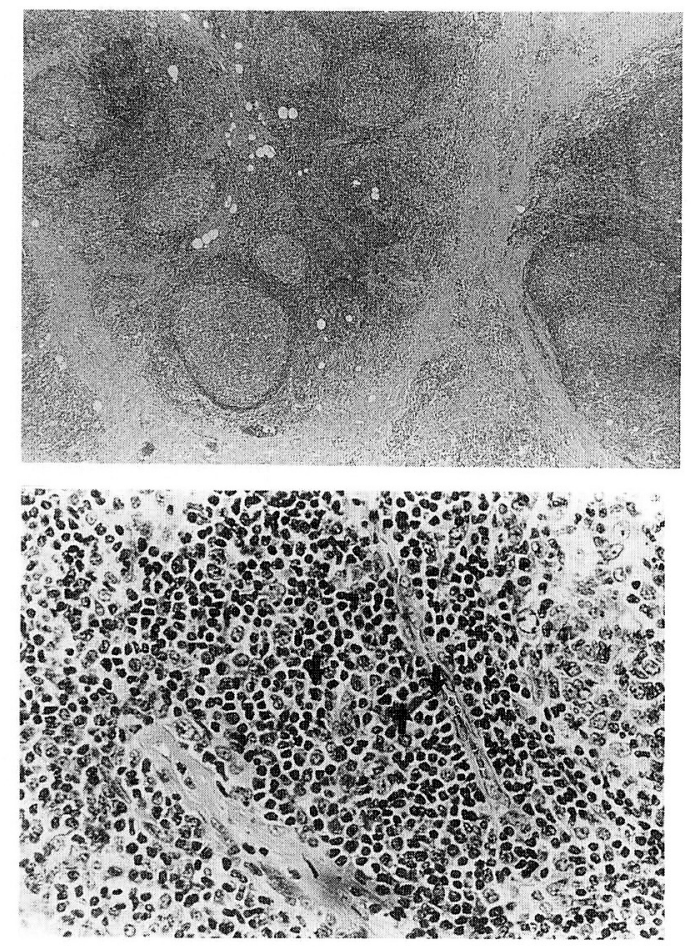

図 3 上段 : 膠原線維と思われる結合織中に，大 小さまざまなリンパ瀘胞様構造の増 生を認める。 $(\mathrm{H}-\mathrm{E} \times 20)$

下段：瀘胞様構造間に, リンパ球, 形質細 胞に混じって好酸球 (矢印) の浸潤 を認める。 $(\mathrm{H}-\mathrm{E} \times 100)$
1 ケ月後には腫瘤の増減に関わらず増加する例 を認めた。好酸球百分率に拈いて，治療直後に 正常範囲近くまで低下した症例 5，6，8は他の 症例と比べ再燃期間が 4 年以上と延長していた。 IIII清 IgE 值は臨床症状と一致せず, 腫瘤縮小 後も高值を示し，長期的に経過を追ら必要があ るように思われた。

\section{考察}

軟部好酸球肉芽腫は，1948年木村，石川112) らが耳下腺揖よび颌下腺に発生した無痛性腫脹 の症例にたいして Mikulicz 病, Uveo-parotid Tuberuclosis などとは異なった病理組織像を 認め eosinophilic lymphoid granuloma と記し たことに始まる。飯塚 ${ }^{3)}$ は自検例11例を検討し， 臨床扣上び組織像上り骨, 皮虐, 肺等に発症す る好酸球肉芽腫とは異なった独立疾患であると し，木村病と命名することを提案した。ささらに 腫脹リンパ節の沪胞構造の破壊像を指摘し, 増 生リンパ組織との組織学的相違を指摘したが, 免疫組織化学的に検索した石川4)らは IgE の局 在ではほぼ同様であると報告している。

病理組織像4)では, (1)膠原線維からなる結合 組織中に大小さまざまなリンパ沪胞様構造の増 大がみられる。(2)沪胞周囲に好酸球, 形質細胞, リンパ球, 肥満細胞の浸潤をみる。 (3)洰胞様構 造の中心は二次小節の肧中心に一致する構造を 認め, 周囲に成熟したリンパ球が層状に配列す る. (4)沪胞中心部には小血管の活かに樹枝状細 胞が存在しエオジン好性の物質が認められる.

本症の原因は現在でも不明である，竹中5）ら は末梢血中の $\operatorname{IgE}$ の増加, 病巣部の肥満細胞 や IgE の局在性より atopic allergy を示唆し, 佐々木6)7 らは患者血清中にカンジダに対する 抗体を証明し, 組織中の IgG と $\mathrm{C}_{4}$ の存在を明 らかにし, Arthus 型反応を示唆している.

臨床的特徵については, アジア地域, 特に本 邦での報告例が多く，欧米での報告8) は少なく， 人種, 地域差がある. 男性に多く, 青少年期か ら壮年期にかけて発生しやすく, 腫瘤の経過が 比較的緩慢なことや自覚症状にそしいことなど 
より受診が遅れることである，石井9）によると 男女比は， 6.3 対 1 の割合で, 平均発症年齢は 24.8 歳であった. 我々の症例も 11 例中 8 例と男 性に多く，4歳～60歳に発症しており，壮年期 以下（45歳以下）が11例中 8 例であったが，平 均発症年齢は37.8歳であった。

好発部位については，73.9\%が頭頸部に発生 し, 耳下腺部, 頸部, 顎下腺部の順になってい る9)。当科に拈いても 7 例は耳下腺部発症であ り，らち 1 例は, 患側同一側の耳管開口部に腫 瘤を認めた。富樫 ${ }^{10)}$ は上咽頭に発生した症例 を報告しており， 口腔粘膜下に腫瘤を認める報 告例11) もめり, 粘膜下組織にも同様の組織性 変化をらかがわせる。

臨床的特徵として, 腫瘤は拇指頭大から小児 頭大までさまざまで可動性はよいが皮膚と癒着 する例がみられ, 自発痛, 圧痛はなく, 局所搔 痒感, 局所色素沈着を伴らことが多い。 また腫 瘤の消退と腫脹を繰り返す例もある. 症例 5 で は季節性の増大を認めた。

臨床検査上の特徵である末梢血中の軽度〜 高度の白血球増加, 高好酸球血症に加光, Bennich ${ }^{12)}$ らが好酸球肉芽腫(分野不明)の患者 で, $\operatorname{IgE}$ の著名な増加を報告して以来, 高 $\mathrm{IgE}$ 血症が臨床症状, 病理組織像と合わせて同症の 診断の一つの要素となっている. 好酸球と $\mathrm{IgE}$ 抗体の関係については, T cell, B cell の関与に より産生された $\operatorname{IgE}$ 抗体 ${ }^{13)}$ が肥満細胞と結合 し, 末梢血中好酸球の組織への遊走を促す化学 物質 (ECF-A)を誘発させ ${ }^{14) 15)}$ ，逆に好酸球は $\mathrm{IgE}$ 免疫複合体を選択的に貪食する作用を有す ることが知られている16)。 また血中好酸球が低 下しても血中 $\operatorname{IgE}$ 值は高值を保つことが多く， $\operatorname{IgE}$ 産生は比較的安定であることが示唆されて いる.

自検例では治療直後には白血球, 好酸球の低 下寸る例が注とんどであったが，IgE は逆に増 加する例もみられ，治療後も高值を示した。 た好酸球が治療法に関係なく治療直後に正常範 团近くまで低下した症例に関しては，再燃しに
くい印象を得，予後の判定に役立つと思われた。 治療法は発生機序が不明なため, 現在でも確 立されたものはないが, 手術療法, 放射線療法, ステロイド療法, 抗アレルギー療法が主体とな っている. しかし，いずれの場合も再燃しやす い. 手術療法は腫瘤が浸潤性であり耳下腺部な どでは顔面神経損傷の危険性もあるため en bloc に摘出できない難点がある．綿貫11) らは, 手術例11例につき 9 例が再燃したと報告してい る. 我々は 2 例に括いて摘出術を施行したが, いずれも 1 年半以内に再燃した。放射線治療は, 本症が良性の疾患であり, 発症, 治療年齢が青 少年期にあたる例が多いこと， Radiation cancer の原因となる問題を残寸が，腫瘤が治 療に反応しやすいことなどより first choice と する文献11) もある. 黒川17) らはリニアックと コバルト照射を行い，照射に反応して効果が現 れてくるのは $20 \mathrm{~Gy}$ であり $40 \mathrm{~Gy} \sim 45 \mathrm{~Gy}$ が腫 瘤の消失には必要であるとしている. 我々は 5 例につき放射線単独でリニアック $20 \mathrm{~Gy}$ 患部 に照射した。腫瘤は $10 \mathrm{~Gy}$ 照射前後から縮小し はじめ, 照射終了後も 2 週間程度まで縮小し, 消失または軽減した。経過を追えた 3 例のうち, 症例 9 は 7 ケ月後に再燃したが，症例 3 は 2 年 3 ケ月後も再燃なく, 症例 7 は 7 年半後に再燃 している，放射線単独または併用療法で治癒せ しめた報告例では，長期にわたって経過を追え た例は少なく，生体に対する浸襲を最少限に同 症の再燃を抑えるには，線量的には $20 \mathrm{~Gy}$ で十 分と考える.

ステロイド療法は北村18) の使用報告以来, 多数の報告例があるが，コントロールが困難で 再燃しやすく19)，患者にとっても長期間服用の 苦痛を強いられる. 我々が経験した 2 症例のら ち症例 6 はプレドニン $60 \mathrm{mg}$ より漸減し, 治 療開始 1 ケ月で腫瘤の消失をみた比較的順調な 例と思われる。また放射線とステロイドの併用 した症例 5 では線量が $35 \mathrm{~Gy}$ と他の症例に比べ 多いが，6年半再燃を見ておらず，放射線少線 量とステロイドの併用療法が有効と思われた。 
抗アレルギー療法に関して, 本症の病態が I 型，III型アレルギーに起因すると考兄られ，力 ンジダ陽性患者に皮内および腫瘤内の減感作療 法を行い，有効であった症例7) が報告されて以 来,アレルギー性鼻炎を合併した症例に DSCG 点鼻液を使用し改善した症例 ${ }^{20)}$, chemical mediators の遊離抑制剂である tranirast を使用 した報告21) がある.我々は 3 例に即時型皮内 反応を施行したがカンジダを含めて陰性であっ た。しかし治療後にカンジダ皮内反応陽性にな った例20) や放射線と併用して軽快せしめた報 告22) もあり，今後検討する必要があると思わ れた。

\section{結語}

我々は開院以来20年間に経験した好酸球性肉 芽腫症（木村病）11例を臨床的立場より報告し た.

1. 臨床所見において耳下腺部発症の症例で, 耳管開口部腫瘤を伴った例を認め, 同疾患が粘 膜にも影響をおよぼすと思われた。

2. 治療直後の末梢血好酸球百分率が正常範 囲に近い汇ど再然しにくいと思われ，今後の予 後の判定に有効と考える.

3. 放射線終了後も腫瘤は縮少傾向を示し消 失した例もあり，生体に拈上ぼす浸襲度を考虑 すれば，総量は $20 \mathrm{~Gy}$ で十分と思われた。

4. 同症は再燃しやすく, 今後の経過を追わ ねばならないが放射線とステロイドの併用が有 効であるように思われた。

本論文の要旨は第52回日本耳鼻咽喉科学会神奈川 地方部会学術講演会にて発表した。

稿を終えるに臨み御指導, 御校閲いただきました, 北里大学医学部耳鼻咽喉科学教室設楽哲也教授に深 謝いたします。

\section{参考文献}

1）木村哲二，吉村三郎，石川栄世 : 淋巴組織増生 を伴う異常肉芽に就いて。病会誌 $37: 179$ 180, 1948.

2）木村哲二，吉村三郎，石川栄世：淋巴組織増生 を伴う異常肉芽について．第11回東京病理集団
会記事. $10 \sim 14,1948$.

3）飯塚 栄: 好エオジン球性リンパ腺炎およびリ ンパ肉芽腫症一木村氏病の提唱一. 日大医誌 18 : 900 908, 1959.

4) 石川栄世, 田中寿子, 柿本慎一, 他 : 好酸球性 リンパ洰胞様構造増生性肉芽腫（木村氏病）の 病理学的研究. 日網内誌 $20: 137 \sim 148,1980$.

5）竹中 徹, 奥田 稔, 宇多弘次, 他 : 軟部好酸 球肉芽腫症の組織学的, 免疫学的研究. 臨床免 疫 $7: 911 \sim 918,1975$.

6）佐々木好久, 山田 登, 久松健一：軟部好酸球 肉芽腫とアレルギー。耳喉 $43 ：$ 195〜200, 1971.

7）佐々木好久, 中原 晧, 村上 泰, 他：軟部好 酸球肉芽腫症（アレルギー学的側面）と Sjögren 病(鼻粘膜の組織学的変化).耳鼻 24 : 910 916,1978.

8) Tseng-tong Kou, Lee-Yung Shih and HengLeong Chan : kimura's disease involvement of regional lyph nodes and distinction from angiolymphoid hyperlasia with Eosinophilia. The American of Surgical Pathology 12 : 843 854, 1988.

9) 石井正則 : 木村氏病について一 4 例の経験と本 邦429例の統計的観察一. 耳展 $25: 407 \sim 416$, 1982.

10）富樫紀彦，宮崎大介，落合洋一郎，他：軟部好 酸球肉芽腫の 2 例, 一附 : 本邦116例の統計的 観察一.耳鼻臨床 $69: 927 \sim 933,1976$.

11）綿貫 喆, 栗根康行: 軟部組織の好酸球肉芽腫 についてー12例の経験と文献的考察一. 臨外 $17: 5 \sim 17,1962$.

12) Bennich H, Gunnar S and Johansson O : Structure and Function of Human Immunoglobulin E. Advances in Immunol $13: 1 \sim 55,1971$.

13）永井朝子, 安達光宣, 淀井淳司: $\operatorname{IgE}$ 産生の制

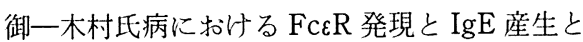
IgE 産生異常について一. 臨床科学 $21: 731$ $737,1984$.

14) Isizuka $K$, Tomiyma $H$ and Isizuka $T$ : Mechanisms of passive sensitization, I. Presence of $\operatorname{IgE}$ and $\operatorname{IgG}$ molecule on human leukocytes. J Immunol 105 : 1459 1467, 1970.

15) Tomioka $\mathrm{H}$ and Isizuka $\mathrm{K}$ : Mechanisms of passive sensitization II. Presence of receptors 
for IgE on monkey mast cell. J Immunol 107 : 971 978, 1971.

16）竹中 徹, 前田次郎, 奥田 稔: 免疫・アレル ギーと好酸球. 臨床病理 $29: 1185 \sim 1193,1981$.

17）黑川久枝, 北香 隆, 黒川茂樹, 他 : 軟部好酸 球肉芽腫（いわゆる木村病）の放射線療法. 癌 の臨床 $18: 712 \sim 716,1972$.

18）北村 武：唾液腺疾患のいろいろ一Mikulicz 氏病について一。聑喉 $29: 844 \sim 850,1957$.

19）石川浩一，上垣恵二，菱本久美郎：軟部好酸球 肉芽腫. 日本臨床 $22 ： 126 \sim 136,1964$.

20）内藤健晴, 妹尾淑郎, 桜井一生, 他: 軟部好酸
球肉芽腫症の 2 症例. 耳鼻臨床 $76: 1174 \sim 1181$, 1983.

21）高野信也, 黒田一, 相馬 恵: 治療に抵抗し た軟部好酸球肉芽腫症の一例. 昭医師会誌 46 : 575 579, 1986.

22）本田哲朗, 由井宏道, 内田 清, 他: 軟部好酸 球肉芽腫の治療経験. 耳鼻臨床 $77: 47 \sim 51$, 1984.

別刷請求先 : 鎌田利彦

于228 相模原市北里 $1-15-1$

北里大学医学部耳鼻咽喉科学教室) 